\title{
Food Safety and Antimicrobial Resistance an Approach to the Genus Salmonella spp.
}

\author{
Alejandro de Jesús Cortés-Sánchez ${ }^{*}$, Raquel Garcia-Barrientos ${ }^{2}$, Hugo Minor-Pérez ${ }^{3}$, \\ Octavio Dublán-García ${ }^{4}$, Alejandra L. San Martin-Azocar ${ }^{5}$
}

\author{
${ }^{1}$ Secretaria de Salud, Comisión Federal para la Protección contra Riesgos Sanitarios, Control Analítico, Departamento de \\ Microbiología, Calz. De Tlalpan 4492, Tlalpan, Ciudad de México, México \\ ${ }^{2}$ Lab de Procesos Biotecnológicos, Universidad Politécnica de Tlaxcala, Av. Universidad Politécnica No. 1, San Pedro Xalcaltzinco, \\ Tepeyanco Tlaxcala, México \\ ${ }^{3}$ División de Ingeniería Química y Bioquímica, Tecnológico de Estudios Superiores de Ecatepec, Av. Tecnológico s/n Esq. Av. \\ Carlos Hank González (Av. Central), Col. Valle de Anáhuac, Ecatepec de Morelos, Estado de México, México \\ ${ }^{4}$ Facultad de Química, Universidad Autónoma del Estado de México, Avenida Paseo Tollocan S/N, Toluca, Estado de México, \\ México \\ ${ }^{5}$ Instituto Tecnológico y de Estudios Superiores de Monterrey, Escuela Superior de Ingeniería en Alimentos, Biotecnología, \\ Agronomía. Av. Epigmenio González 500, Santiago de Querétaro, México
}

Email: *alecortes_1@hotmail.com

How to cite this paper: de Jesús CortésSánchez, A., Garcia-Barrientos, R., MinorPérez, H., Dublán-García, O. and MartinAzocar, A.L.S. (2017) Food Safety and Antimicrobial Resistance an Approach to the Genus Salmonella spp. Journal of Biosciences and Medicines, 5, 55-71.

https://doi.org/10.4236/jbm.2017.52006

Received: January 24, 2017

Accepted: February 20, 2017

Published: February 23, 2017

Copyright (c) 2017 by authors and Scientific Research Publishing Inc. This work is licensed under the Creative Commons Attribution International License (CC BY 4.0).

http://creativecommons.org/licenses/by/4.0/

\begin{abstract}
Foodborne Illnesses (FI) are considered an important problem in public health for their high levels of morbidity and, in some cases, of mortality in Mexico and around the world. Different agents that cause Foodborne Illnesses, in which biological agents such as the genus Salmonella spp., are included, have been often associated with outbreaks. A continued effort has been observed in the food industry, in collaboration with sanitary authorities on a global scale, through the creation and continued improvement of different procedures to prevent the contamination by Salmonella, in which the elaboration of laboratory methodologies for the detection and isolation of this pathogen in foods and, in such manner, prevents the outbreak of illnesses. However, along with the aforementioned, it has been reported that a few years ago, the appearance of an ever-increasing number of strains of Salmonella spp., in foods with multi-drug resistance to antibiotics which are used in the treatment of its illness, results in a major emphasis on the health issue related to Foodborne Illnesses and, in particular, to those generated by factors of medical dependence such as the increase in recuperation time, costs, and reduction in the number of alternative pharmaceutical treatments. This work presents a general overview of FI, in which illnesses generated by bacteria of the genus Salmonella spp., their detection in a microbiological laboratory, as well as the phenomenon of resistance to antibiotics by these bacteria, and the current and difficult issue reported through different investigations all around
\end{abstract}


the world, of the rise in this phenomenon and its importance in public health, are discussed.

\section{Keywords}

Health, Salmonellosis, Salmonella, Food Safety, Antimicrobial Resistance

\section{Introduction}

Humanity has always had the need to search for food to survive. Just recently, a tendency in the diet of the population has risen, and it is the interest in consuming foods free of illness-causing agents, which has placed the spotlight on food safety and nutritional characteristics such as organoleptic and commercial traits. Both safety and nutrition have become the hallmark of quality in foods [1]. Foodborne Illnesses are considered syndromes originated by the ingestion of water and foods which contain etiological agents in quantities such that they affect the health of the consumer at an individual level or in population groups [2] [3] [4] [5]. These illnesses constitute an important sanitary issue due to their impact on public health, being responsible for the elevated levels of morbidity and, in some cases, of mortality in developed and developing countries, primarily affecting those with low income and population groups such as children, pregnant women and the elderly [3] [5] [6] [7] generating considerable loses in some parameters of public health, animal health, food industry, implementation and monitoring of safety policies in foods and, of course, the perception and trust of the consumers [3] [7] [8] [9]. Approximately, there are around 250 causative agents of Foodborne Illnesses, in which chemical physical, and biological agents are included. Those of biological origin, particularly bacteria such as Salmonella spp., Listeria monocytogenes, Campylobacter spp., Shigella spp., and Escherichia coli 0157:H7, are frequently identified in outbreaks [7]. Foods of animal origin, such as meats, birds, fish and seafood that are poorly cooked, or eggs and milk that is not pasteurized, are those foods generally implicated in outbreaks of Foodborne Illnesses [1], in which different factors, such as globalization of the market, increase in the populations at risk (immunosuppressed), introduction of new products and fabrication methods, tendencies observed in eating habits, the rising demand for ready-to-eat foods (which require a longer and more complex production process) have lead to a greater risk of microbiological contamination of foods and consequently, of Foodborne Illnesses [6] [7] [10], coupled with the potential relationship between socio-demographic factors such as the aging of the population, which could also be contributing to the apparition of these illnesses [8].

This work presents a general overview of Foodborne Illnesses, and particularly those generated by bacteria of the genus Salmonella spp., its detection in the microbiology department, as well as the phenomenon of multidrug resistance by these bacteria, and the current and difficult issue reported through different in- 
vestigations all over the world, of the rise in this phenomenon and its importance in public health.

The total scope of Foodborne Illnesses is generally an unknown; however estimations have been calculated concerning their impact in various countries around the world. In the USA alone, in 2012, 831 outbreaks of Foodborne Illnesses were registered, with Salmonella spp. being confirmed as the causative agent in $69 \%$ of the outbreaks, while in the European Union, 5648 outbreaks of Foodborne Illnesses during the year 2011, in which the causative agents were primarily Salmonella spp., and Campylobacter spp., their respective infections being the zoonosis (illnesses transmitted from animals to humans), with major prevalence in developed countries. Meanwhile, in countries such as Chile, Foodborne Illness outbreaks in which Salmonella spp. was identified as responsible for 2013 were 54\% of 1164 total outbreaks [7]. Currently, in Mexico, the real incidence of Foodborne Illnesses is still unknown, as a consequence of not reporting the outbreaks to the sanitary authorities, in cases in which contaminated foods were the origin of the illnesses [1]. However, gastrointestinal illnesses are one of the primary reasons for medical visits, as well as one of the primary causes of death. These illnesses can appear in any time of year, but are particularly more common during spring and summer, when associated to bacteria (Escherichia coli, Salmonella spp., and Shigella spp.), parasites (Giardia lamblia and amoebas), and viruses (Rotavirus and Norwalk virus), derived from the consumption of food and water contaminated with fecal matter. The most commonly-found illness is gastroenteritis, and the most characteristic clinical manifestations are: fever, vomiting, abdominal pain, and moderate to intense diarrhea. In 2008 alone, the Mexican Institute of Social Security (IMSS) reported 2, 188,000 medical visits due to gastrointestinal illnesses, being Chihuahua, Coahuila, Jalisco, Michoacán, Guerrero, and Oaxaca the states with the most incidence [11]. Salmonellosis is a gastrointestinal illness transmitted mainly through the consumption of seafood, vegetables, milk, or contaminated dairy products and is considered the zoonosis with the most prevalence in developed countries, and is one of the most common causes of gastroenteritis in babies and children. This illness is caused by Salmonella spp., a genus which boasts more than 2500 serotypes. The serotypes that have been isolated most often in Mexico are: Typhimurium, Enteritidis, Derby, Agona and Anatum. All the serotypes have different degrees of adaptability and pathogenicity. For example, Salmonella entérica serotypes Typhi and Paratyphi cause severe illnesses in humans, such as septic syndrome, typhoid, and paratyphoid fever. There are reports of epidemiologic surveillance from the year 2008, in which 5000 and 12,000 cases of typhoid and paratyphoid fever in Mexico, respectively, are mentioned [11].

\section{Salmonella and Foods}

The genus Salmonella spp., is made up of bacteria that belong to the Enterobacteriaceae family. They are often found in the intestine of human beings and animals, often causing intestinal pathologies, feces being the main source of food 
and water contamination [12] [13] [14] [15]. They are Gram-negative bacilli, catalase-positive, oxidase-negative, aerobic and facultative anaerobes, and do not produce spores, metabolize glucose, maltose and mannitol, but not lactose or sucrose, are producers of sulfhydric acid, are mobile (since they possess peritrichous flagella), and also possess fimbriae and pilis. In its taxonomic classification, there are 2 species; $S$. entérica and $S$. bongori. The first also subdivides into six subspecies: enterica, salamae, arizonae, diarizonae, houtenae and indica, in which Salmonella entérica, subspecies entérica, representing 99\% of the serotypes that have been isolated and have been found responsible for infections in man and hot-blooded animals, encompassing approximately 1586 serotypes [16]. They present 3 main antigens, which determine the serotype, such as somatic $\mathrm{O}$ (cell wall lipopolysaccharides), flagellate $\mathrm{H}$ (proteins of the mobile flagellum), and antigen Vi of virulence (thermos labile polysaccharide of the capsule). The serotypes are frequently classified under the Kaufmann-White system [13] [15] [16] [17] [18]. As a pathogen, Salmonella possesses different virulence factors, such as adhesion, invasion, and genes related to the production of toxins, which are all congregated in areas of the chromosome called pathogenicity islands, and can be localized in the chromosome or plasmids. In $S$. typhi, for example, 15 islands of pathogenicity have been found [15]. Infection by bacteria of the genus Salmonella spp., originates through the oral route, with the ingest of contaminated foods and water, or fecal-oral infection. The latter presents different clinical forms depending on the species and host, resulting in 5 clinical syndromes: 1) acute, asymptomatic infections, 2) gastroenteritis, 3) bacteremia, 4) enteric fevers (typhoid and paratyphoid fevers), 5) and a state as a chronic asymptomatic carrier [12] [13] [18] [19].

Infection by any bacteria of the genus is called Salmonellosis, which is one of the most common and most extended foodborne illnesses [20] [21]. It is estimated that Salmonellosis affects dozens of millions of people all over the world annually and leads to the death of at least 100,000 people [21]. The three most important and relevant species of the genus are: Salmonella typhi, Salmonella choleraesuis, and Salmonella enteriditis [13]. The members of the genus Salmonella spp. are frequently involved with foodborne illnesses. The rise in infections throughout the world is considered important in an economic sense, as well as in public and animal health. Some foods such as chicken, beef, pork, eggs, fish, milk and other fresh products are common sources of infection by these bacteria [12] [15]. Salmonella has traditionally been associated with poultry and egg products, and fresh products as alfalfa sprouts, baby spinach, basil, cantaloupe, lettuce, peppers, and tomatoes have been found to be contaminated with this organism [22].

One food one must be especially cautious when consuming is ground beef, since it is an ideal medium for the growth of Salmonella due to its nutritional content and absence of inhibiting agents, in such a way that these foods have been frequently identified as responsible of outbreaks related with this pathogen [15] [23]. Legislation has been established around the world in order to guaran- 
tee the safety of foods with regards to Salmonella. Thus, the European Union has established documents such as regulation (CE) No 2160/2003 of the European Parliament, established the 17th of November, 2003

(http://eurlex.europa.eu/LexUriServ/LexUriServ.do?uri=CONSLEG:2003R2160: 20071027:ES:PDF), concerning the control of Salmonella spp., and other specific zoonotics related with foodborne illnesses, as well as regulation (CE) No. 2073/2005, from the meeting on the 15th of November, 2005, over applicable microbiological criteria to food products such as meats, dairy products, eggs, amongst others, in which the presence of Salmonella must be absent in $25 \mathrm{~g}$ (http://eurlex.europa.eu/LexUriServ/LexUriServ.do?uri=CONSLEG:2005R2073: 20100519:ES:PDF). In Mexico, various official norms have been established, which make reference to laboratory test methods for the detection of indicative microorganisms, Salmonella, and other pathogens in foods, such as NOM-210SSA1-2014 [24], as well as microbiological specifications, that include the genus Salmonella spp., for various foods, al-lowing the control in quality and safety of the foods aimed for consumption by the Mexican population in such a manner that they no longer represent a health risk. One example of this is the official norm NOM-243-SSA1-2010 [25], in which sanitary dispositions and specifications, test methods for milk, milk formula, and combined dairy products, are mentioned. NOM-242-SSA1-2009 [26] makes reference to fresh seafood products, as well as refrigerated, frozen and processed seafood products. The norms are applicable to foods commonly commercialized and consumed in Mexico, and whose established maximum microbiological content is absence in 25 grams.

\section{Analysis in the Microbiological Laboratory}

Currently, the identification of bacteria is done through conventional methods based on phenotypical characteristics (morphology, development, biochemical and metabolic properties), due to the fact that it does not implicate a great cost, which makes them accessible. When obtaining a culture in culture media is possible, it is the diagnostic method of choice, since it allows for the isolation of the microorganism implicated, as well as identification, susceptibility studies to antibiotics and allows for the application of epidemiological markers [27] [28].

However, there are inherent problems with the phenotypical identification due to the absence or little concordance between the observable characteristics of the wild type and the reference strain, or that they are difficult to culture. In order to solve the inherent problems presented by these systems of phenotypical identification, genetics-based methods of bacterial identification, such as complimentary or alternative procedures where, through the diversity of genes that have been utilized as molecular targets in taxonomic studies or in the phylogeny of the different genus and bacterial species, constitute the analysis of 16S rRNA, the initial and sufficient marker to achieve a more precise identification. Likewise, microbial protein-based identification methods have been proposed and utilized for several years now The most used techniques, in this sense, are elec- 
trophoresis and MALDI-TOF (Matrix-Assisted Laser Desorption/IonizationTime Of Flight) mass spectrometry, which is typically integrated with MALDI ionization sources. MALDI-TOF mass spectrometry is a technique whose advantages are its high rate of identification, speed, no need for pre-selection, simplicity in its uniform preparation, robustness and reliability under variable conditions, and the low cost of its reagents. However, amongst its limitations and disadvantages, it requires frequent calibrations and quality control measures, extreme care in the standardization of the inoculum, a limited number of references in the database, and is essential training of the users, reasons for which it represents a potential alternative [27] [28]. The analysis of the isolate and identification of bacteria that form part of the genus Salmonella spp., in foods, is generally for: determining if this microorganism is or was involved as a causative agent of outbreaks related to foodborne Illnesses, or if certain foods or bulk materials are sources of contamination and thus represent a risk to the consumer's health. There are different traditional methods of analysis which are based on different phases and work conditions in the laboratory, but that also include phases of pre-enrichment, selective enrichment, isolation in selective and differential culture media, biochemical identification and serological confirmation of the microorganisms (Figure 1 and Table 1). Amongst some of these methods, there is one developed by Wallace et al. [29], present in The Manual for Bacteriological Analysis of the Food and

(http://www.fda.gov/Food/FoodScienceResearch/LaboratoryMethods/ucm07014 9.htm). In Mexico, it is established in the international norm ISO 6579.2002

Table 1. Biochemical and serological tests for the identification of Salmonella spp. in the microbiological laboratory [29] [31].

\begin{tabular}{cc}
\hline Analysis & Reaction of species of Salmonella spp. ${ }^{1}$ \\
\hline TSI (production of acid from glucose) & + \\
Lysine decarboxilase (LIA) & + \\
$\mathrm{H}_{2} \mathrm{~S}$ in TSI and LIA & + \\
Hydrolysis of urea & + \\
Lysine decarboxilase broth & - \\
Methyl red & $-\mathrm{c}$ \\
Voges-Proskauer & - \\
Malonate broth & V \\
Production of indole & + \\
Citrate & Agglutination + \\
Mobility & Agglutination + \\
Polyvalent somatic (o) test & \\
Polyvalent flagellar (h) test &
\end{tabular}

(LIA): Lysine Iron Agar; (TSI): Triple Sugar Iron Agar; ${ }^{1}+:$ 90\% or more positives in 1 or 2 days; ${ }^{1}-:$ 90\% or more negatives in 1 or 2 days; v: variable; c: most of the $S$. arizonae cultures are positives. 


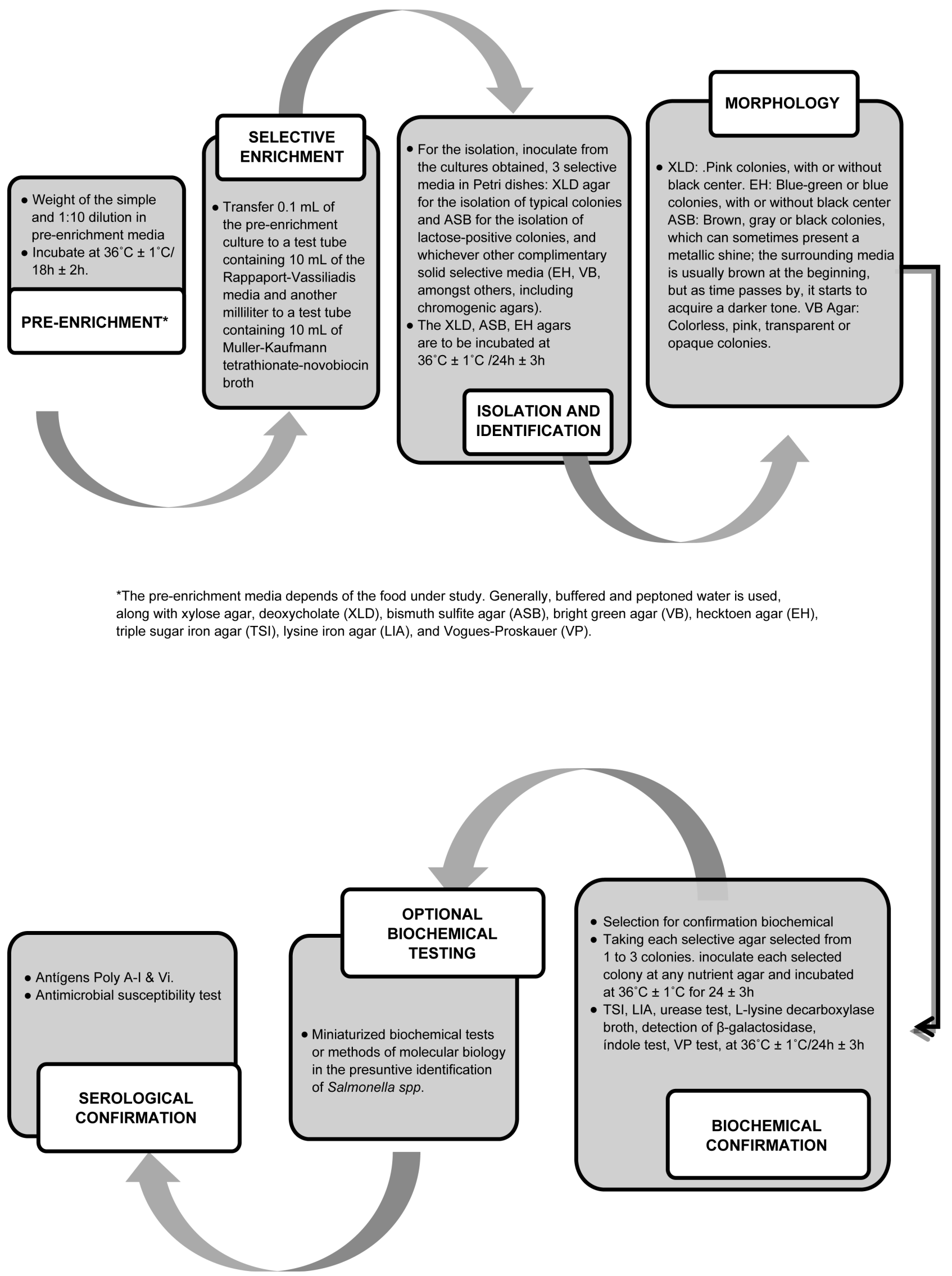

Figure 1. Flowchart for the isolation and identification of Salmonella spp. in foods [24] [30] [31]. 
[30], "Microbiology for foods consumed by humans and animals", or the official methods in effect in Mexico, such as official norm NOM-210-SSA1-2014 [24], "Products and services, microbiological test methods, determination of indicative microorganisms, and determination of pathogenic microorganisms". It is also important to note that this has also been done through modern biochemical methods or rapid tests based on molecular biology. In Figure 1, some of these tests can be seen. Some of the methods used are commercial kits used for the detection of Salmonella typhi, but there are very few for the detection of Salmonella typhimurium. Recently, Mutreja et al. [10], developed an antigen-based biomarker, which functions as an immunosensor based on the measurements of electrical impedances for the detection of this serotype in water and samples of juice, with favorable results.

\section{Susceptibility to Antimicrobials}

Multi-drug resistance was reported for the first time in members of the family of enterobacterial such as Escherichia coli, Shigella spp., and Salmonella spp. at the end of the 1950's as part of the indiscriminate use of antibiotics, resulting in the acquisition of resistance by other microorganisms. Bacterial resistance is considered to be still on the rise and represents a public health issue that has been observed globally. The challenges for the treatment of infections acquired, in the community, as well as in the hospital, are considerable. In the United States of America alone, it is estimated that between $50 \%-60 \%$ of more than 2 million hospital infections are caused by resistant bacteria [32] [33] [34]. For several years now, considerable advances in data and the understanding of the responses in bacteria towards antimicrobial agents have been achieved. Thus, the resistance of microorganisms to antibiotics and chemotherapeutic agents could be due to two possible explanations: 1) it is an innate ability (in the case of enterobacterial towards macrolides), or 2) it is an acquired ability that results from mutation or through the acquirement of DNA in the form of plasmids or transposons, which are transferred from one microorganism to another. Bacteria can also present resistance to antibiotics as a result of chromosomal mutation or through the exchange of genetic material through the transport of resistance genes that follow four different mechanisms: 1) consistent conjugation in the transfer of plasmids that confer resistance from one bacteria to another, through the sexual strand, 2) transformation, which is the transfer of genes from the naked DNA of a lysed bacteria to another, which incorporates it in its genome, 3) transduction, which is the transfer of any part of a bacterial genome to another, done by bacteriophages, and 4) transposition, which is the transfer of a section of DNA (transposon) that includes resistance genes towards different antibiotics and other genes that together result in the expression of a particular promoter [32] [34].

Once incorporated, the genetic codifying material for the resistance towards antibiotics can be expressed by different microorganisms and, amongst them, are Gram-positive bacteria in various mechanisms such as: 1) enzymatic mod- 
ification or destruction of the antibiotic, through the expression of enzymes capable of creating changes in the structure of the antibiotic, leading to its loss in functionality. Amongst the enzymes capable of such action, there are betalactamases and carbapenemases, as well as other modifying enzymes responsible for resistance, such as methylases, acetyl-transferases, nucleotidiltransferases and phosphotransferases, which specially inactivate $\beta$-glycosides. 2) Excretion bombs are often a mechanism often used by Gram-negative bacteria, which consists in removing the antibiotic from the periplasmic space and expulsing it, thus preventing the antibiotic from reaching its action site. Currently, five "super" families of proteins exist, which are involved in this process: a) family of ATP-binding cassettes (ABC), b) superfamily of major facilitators (MFS), c) multi-drug and toxic compound extrusión family (RND) (MATE), d) Small multi-drug resistance family (SMR), and e) resistance nodulation division family. The most commonly expressed by Gram-negative bacteria, while the most commonly expressed by Gram-positive bacteria are the MFS type. 3) Impermeability to the antibiotic. Bacteria can generate changes in the lipid bilayer through alterations in its permeability, mainly through changes in protein structures called porines, which act as aqueous channels which connect the membrane with the periplasmic space. These porines can vary in number and size. The mutations that alter the form and quantity of the existing porines, will affect the permeability of the antibiotics. 4) Alteration or production of new target sites. This mechanism is mainly employed by Gram-positive bacteria, generating structural changes in the action sites of beta-lactamase antibiotics at the level of union proteins used by penicillins [32] [33] [35], and lastly, another mechanism of resistance, although not one of the main mechanisms previously mentioned, is the formation of biofilms (adherent aggregates that form over surfaces) where producers have demonstrated to be resistant to antibiotics and antimicrobial aggressors. Host response is the most widely-accepted mechanism by which biofilms contribute to resistance, but bacteria present in the biofilm differentiates to refractory states towards antibiotics, which involves a combination of phenomena such as indifference (bacteria that do not divide, or do not have the sufficient nutrients for an active metabolism, and are thus partially or completely resistant to antibiotics) and persistence (the antibiotics do not eliminate all the bacteria in active growth; with the passing of time, the elimination rate of bacteria substantially declines) [34].

Infections in humans by Salmonella spp., usually come to an end after five to seven days, and do not require the use of antibiotics (gastroenteritis), but when some cases progress onto bacteremia or the patients are immunosuppressed, is when antibiotics are necessary [12] [18] [35]. The use of antibiotics is a phenomenon which favors the health of the patient, but indirectly generates processes of selection and the survival of resistant pathogens to the antimicrobial agents employed. The phenomenon of resistance affects all microorganisms, but mainly bacteria, which can be transferred to man, from the environment, through multiple routes such as the food chain. It has been reported that the antibiotics 
which most often generate resistance in bacteria, no matter the route of administration used, are clindamycin, ampicillin, amoxicillin, and cephalosporins, and to a lesser degree, penicillins, quinolones, eritromycin, trimethoprim-sulfamethoxazole, chloramphenicol and tetracyclines [19]. This phenomenon of multiple resistances to antibiotics by enterobacterial and, specifically, Salmonella spp., has been observed in different countries all over the world due to several factors. Amongst them, the abuse of the use of antibiotics in animals as growth promoters, the ingestion of fecal matter by animals, which continue to present the illness after several failed treatments, and finally, the abuse of antimicrobial agents used in agriculture (control of phytopathogens), treatment of persons by medical prescription or auto medication, as well as veterinary prescriptions in the treatment of animals [12] [18] [19] [35] [36] [37]. These actions have brought about some consequences, for example, the prohibition in the use of drugs against Salmonella in some production animals, such as fluoroquinolones in poultry farming. This phenomenon is on the rise, and has significant effects in society, longer hospital stay by prolongation of the illness and rise of sanitary costs [12] [18] [19] [35]. The dissemination of Salmonella spp., resistant to antibiotics in the production lines of foods of animal origin, is also considered as a problem of public health on a global scale [38].

The resistance in microorganisms such as Salmonella spp., is obtained by the transfer of extra chromosomic genetic material (plasmids, tramposons or integrons) from other bacteria, or through mutations in the bacterial chromosome, which are phenotypically expressed through biochemical mechanisms, which are based on diverse actions such as impermeability, inactivation, expulsion, deviation, and alteration of the target cellular component, giving way to the protection against antibiotics, as occurs in the mutation of the DNA gyrase and topoisomerase IV (target proteins for quinolones) [18] [35].

Microorganisms, having the capability of exchanging genetic material and thus acquiring the trait of resistance towards antimicrobial compounds, increases the possibility of dissemination of microorganisms with this characteristic It is considered that the risk of acquiring bacterial carriers of resistance genes through foods is owed to two mechanisms, which are the transfer of zoonosiscausing microorganisms to man, and the selection that generates this noxious condition for microorganisms in non-pathogenic bacterial populations within the microbiota of the human intestine, since the gastrointestinal tract of humans and animals is considered an ecosystem suitable for the exchange and transfer of genetic mater that confers resistance between bacteria, even when they do not belong to the same genus, and if said bacteria reach this location via foods, it is believed that the dissemination of resistance to antibiotics in bacteria could be favored [19]. Considering the aforementioned, another factor that favors the dissemination of resistant bacteria through foods is the use of animal excrements as a means of soil fertilization, as well as the use of contaminated water for the watering of crops, especially when there is dumping of sewer waste onto these waters without previous treatment, leading to the contamination of vegetables 
and the environment with pathogenic agents and saprophytes as carriers of resistance [19] [39].

In many studies, the focus has been the correlation between the bacteria responsible for illnesses of food origin in humans, and the resistance to antibiotics, which frequently shows an increment, in particular, of Salmonella spp., since this microorganism hardly transfers from human to human, considering foods the main and most feasible source of exposition for man [36]. The serotypes Typhimurium and Enteriditis are those often associated with epidemiological outbreaks (salmonellosis) through the consumption of contaminated water and foods. These serotypes are also those that most rapidly acquire resistance [18] [19]. The aforementioned could be due to the fact that Salmonella typhimurium presents a wide range of hosts such as humans, bovine, porcine, equine, and a variety of wild and poultry birds [37]. While some serotypes such as Salmonella typhi, causative agent of typhoid fever, are known to present multi-drug resistance, ciprofloxacin being the only effective antibiotic against it [18]. However in 2015, Lee et al. [40] isolated first of ciprofloxacin-resistant Salmonella enterica serovar typhi in Taiwan. The emergence and spread of antimicrobial-resistant $S$. typhi infection as a result of international travel may become a threat to public health in Taiwan.

In studies done by various countries around the world, including Mexico, the rise in outbreaks reported, as well as the resistance to antibiotics of this genus, are noteworthy. Baltasar et al. [41] in Spain, investigated the sensibility to 35 strains of Salmonella entérica, obtained from foods of animal origin (fresh meats, meat products and fresh eggs) destined for human consumption, and which were taken between 1998 and 2003, as part of the Sanitary Vigilance of Foods, by the Public Health Administration, in the health centers in the province of Valencia. They reported that only 4 strains were sensible to all the antibiotics tested, and that the rest presented a broad spectrum of drug resistance, in which the most common drugs were: tetracycline, streptomycin, nalidixic acid, ticarciline, ampicillin, and chloramphenicol The serotypes that present the greatest degrees of resistance were 4, 5, 12:i: and Hadar, followed by Typhimurium and Virchow. It is also worth mentioning that the resistance towards some broad-spectrum antibiotics appeared with higher percentages than those described beforehand in foods in Spain, especially in the cases of streptomycin, ampicillin and tetracycline.

In Cuba, where the main Foodborne Illness is salmonellosis, once the study of 72 strains of Salmonella spp., from different foods of 9 provinces, was concluded, the results showed that $19.4 \%$ of the strains were resistant to the battery of antibiotics used [36].

In Mexico, similar studies have been done. López et al. [37] carried out a study of detection and resistance to antibiotics of Salmonella in soil and water used in agriculture in the agricultural valley of Culiacan in the state of Sinaloa, the aforementioned due to the fact that the region has been considered for the last 50 years as the main production zone and exporter of vegetables of the country, 
besides the fact that the that the fresh fruits and vegetables are capable of acting as vehicles for a wide variety of pathogenic microorganisms for man, and where the microbial contamination, irrigation water and soils, are considered the main sources that cause the loss of safety in foods. The researchers reported that the presence of Salmonella spp., could not be determined in soil samples, and that the negative results do not suggest the absence of the bacteria, but rather the impossibility of bacterial growth due to the environment's hostile conditions, however, for samples of water, 20 strains of Salmonella were isolated, including the Infantis, Oranienburg and Anatum serotypes, which have been linked to outbreaks of gastroenteritis due to the consumption of fresh fruits and vegetables, as well as the Give, Agona, Minnesota and Typhimurium, the last of these having the most frequency. The $60 \%$ of the strains isolated presented resistance to tetracycline, all these corresponding to the Typhimurium serotype, while $100 \%$ was susceptible to ampicillin, ciprofloxacin and trimethoprim-sulfamethoxazole.

Nayarit-Ballesteros et al. [42] reported on a study of the resistance profiles to antibiotics of serotypes of Salmonella spp. Isolated from ground beef issued to different supermarkets, butcheries, public markets and flea markets in Mexico City. In supermarkets, the positive samples were 6\% (3/50), while less informal establishments (flea markets, butcheries and public markets) was 32\% (16/50). The serotypes that were found were Lomita, Derby, Senftenberg, Javiana and Cannstatt, recognized as the causative agents of the infections transmitted through foods in people in Mexico and other countries. It also mentions that between $70 \%$ and $95 \%$ of the strains presented resistance to antibiotics (ampicillin, carbenicillin, tetracycline and trimethoprim-sulfamethoxazole), emphasizing that the percentage is three times greater to that reported by Miranda et al. [43] and evidences the fact that a considerable selection in strains in different segments of the productive chain. It also reports on the resistance to pefloxacine in one strain. This is alarming for the researchers, since pefloxacine is the antibiotic of choice for the treatment of enteric salmonellosis in adults.

Bermúdez et al. [38] did a study of antimicrobial susceptibility towards 10 antimicrobial agents through the diffusion method in discs, of 283 isolates of Salmonella from floors, equipment, utensils and finished products in plants of porcine benefit in Colombia, reporting the presence of 279 multi resistant isolates of Salmonella entérica of porcine origin from the environment and of the finished product in the benefit plants evaluated (46, 64\% n: 132). Detecting 52 patterns of multi resistant, the most frequent was cefthiofur-tetracycline-tilmicosin in $9.89 \%$ (n: 28) of the isolates. With regards to these antimicrobial agents, $96.82 \%$ (n: 274) of the isolates were resistant to tetracycline; $73.14 \%$ (n: 207) to tilmicosin, and $28.27 \%$ (n: 80) to cefthiofur, concluding that the results obtained indicated an important environmental contamination of some porcine benefit plants in Colombia with multi resistant isolates of Salmonella entérica, suggesting that the cleaning and disinfection procedures must be improved as a fundamental part of the quality management and safety systems in benefit plants. Besides the neces- 
sity of promoting the design and implementation of an official program of Antimicrobial Resistance Vigilance, with voluntary monitoring systems in each link of the porcine production chain, which assist in the prevention and control in the prevention and control of the transmission of resistant microorganisms of food origin within the framework of the food safety management system in the South American country. López et al. [44] did a study in the prevalence of multi resistant strains of Salmonella spp., in raw foods (meats and vegetables) in the city of Puebla (Mexico), acquired in public markets and established butcheries, reporting that 80 samples of meat analyzed in different presentations, the percentage of recuperation of the Salmonella spp. strains was of $22.7 \%$, and $2.5 \%$ in vegetables, $100 \%$ of the strains of Salmonella spp., being multi resistant to $2-8$ antibiotics, observing $100 \%$ resistance towards gentamicine and bacitracine, $90.4 \%$ to amikacin, $45.8 \%$ to doxicycline, $41 \%$ to chloramphenicol, $40 \%$ to ampicillin, and $25.3 \%$ to ciprofloxacin.

\section{Prevention of Multi-Drug Resistance through Foods}

Measures must be established through different means so that microorganisms resistant to antimicrobial agents do not reach human beings, through primary production control, as well as establishing effective norms for the regulation and vigilance of food safety, in order to promote hygienic conditions in products such as meats, poultry, eggs, dairy products, fish, vegetables, and fruits, and through the implementation of microbiological quality indicators (Escherichia coli, Enterococcus faecalis and Enterococcus faecium), zoonotic bacteria and human pathogenic agents such as Campylobacter coliljejuni, Salmonella spp., Staphylococcus aureus and Listeria monocytogenes [19] [23] [42]. Another form of preventing intestinal illnesses caused by different microorganisms, including Salmonella spp., is the water treatment, supply and distribution of water to the general population, as well as an emphasis on personal hygiene measures [21]. The World Health Organization (WHO) has emitted a series of recommendations and informative bulletins with the finality of preventing and/or reducing the possibilities of contracting an illness through foods, in which the bacteria present may or may not present resistance towards different drugs. Amongst these recommendations, there is one that before consuming foods, in the case of meat, it be subjected to an efficient cooking process, and proper disinfection in the case of vegetables. Likewise, one is recommended to apply the five key steps to improve food safety, which are: 1) Maintain cleanliness, 2)Separate raw foods from cooked foods, 3) Cook all foods well, 4) Maintain the foods at a proper temperature, and 5) Use clean water and ingredients [23] [44].

\section{Conclusion}

Salmonella is an important etiological agent of gastrointestinal illnesses transmitted through foods, with high incidence in Mexico and the world. Also, there are higher rates of resistance towards antibiotics more often than before, for antibiotics frequently used in medical treatments. Both the phenomenon of resis- 
tance and that of Foodborne Illnesses, represent an important public health issue due to the negative repercussions in health and economy, reason for which measures related to information, vigilance and control in foods safety, must be established, as well as the use of antimicrobial agents in areas such as agriculture, cattle raising, as well as human and animal therapeutics, avoiding the irresponsible use of drugs, as means to combat multi-drug resistance. Until now, diverse studies around the world have given way to the knowledge and understanding of the mechanisms involved in resistance towards antibiotics, which should lead to the prudent and conscious use of existing and future pharmacological treatments. However, more studies are required in regard to this subject and it continues to be a challenge, since resistance seems to be a phenomenon which has no end, considering that the selective pressure to which microorganisms are subjected will result in their development of different mechanisms to neutralize the action of the drug in question, allowing for their means of survival, which can also be transferred.

\section{Competing Interests}

The authors have declared that no competing interests exist about this document.

\section{References}

[1] López, A., Ruiz, A.C., Cabrera, C., León, G. and Tejeda, F. (2014) Prevalencia de cepas multirresistentes de Salmonella spp y Escherichia coli 0157:H7 en alimentos crudos en la Ciudad de Puebla. Ciencias Naturales y Exactas, Guanajuato.

[2] Smith, G. (2013) Food-and Water-Borne Disease: Using Case Control Studies to Estimate the force of Infection That Accounts for Primary, Sporadic Cases. Epidemics, 5, 77-84. https://doi.org/10.1016/j.epidem.2013.04.002

[3] Uribe Meneses, A., Ospino Rodríguez, J. and Forero Niño, C.P. (2014) Estudio de brote de enfermedad transmitida por alimentos. Revista ciencia cuidado, 11, 7-15.

[4] Masana, O.M. (2015) Factores impulsores de la emergencia de peligros biológicos en los alimentos. Revista Argentina de Microbiología, 47, 1-3. https://doi.org/10.1016/j.ram.2015.01.004

[5] Cassini, A., Colzani, E., Kramarz, P., Kretzschmarm, M.E. and Takkinen, J. (2016) Impact of Food and Water-Borne Diseases on European Population Health. Current Opinion in Food Science, 12, 21-29. https://doi.org/10.1016/j.cofs.2016.06.002

[6] Muñoz, A.I., Vargas, M., Otero, L., Díaz, G. and Guzmán, V. (2011) Presencia de Listeria monocytogenes en alimentos listos para el consumo, procedentes de plazas de mercado y delicatesen de supermercados de cadena, Bogotá, DC, 2002-2008. Biomédica, 31, 428-439. https://doi.org/10.7705/biomedica.v31i3.394

[7] Jorquera, D., Galarce, N. and Borie, C. (2015) El desafío de controlar las enfermedades transmitidas por alimentos: Bacteriófagos como una nueva herramienta biotecnológica. Revista Chilena de Infectología, 32, 678-688.

https://doi.org/10.4067/S0716-10182015000700010

[8] Olea, A., Díaz, J., Fuentes, R.V. and Alejandra y García, M. (2012) Foodborne Disease Outbreaks Surveillance in Chile. Revista Chilena de Infectología, 29, 504-510. https://doi.org/10.4067/S0716-10182012000600004

[9] García-Vázquez, E., Hernández-Torres, A., Herrero Martínez, J.A. and Gómez- 
Gómez, J. (2014) Infecciones por Salmonella y Yersinia. Medicine-Programa de Formación Medica Continuada Acreditado, 11, 3322-3326. https://doi.org/10.1016/S0304-5412(14)70777-2

[10] Mutreja, R., Jariyal, M., Pathania, P., Sharma, A., Sahoo D.K. and Suri R.C. (2016) Novel Surface Antigen Based Impedimetric Immunosensor for Detection of Salmonella Typhimurium in Eater and Juice Samples. Biosensors and Bioelectronics, 85, 707-713. https://doi.org/10.1016/j.bios.2016.05.079

[11] Hernández Cortez, C., Aguilera Arreola, M.G. and Castro Escarpulli, G. (2011) Situación de las enfermedades gastrointestinales en México. Enfermedades Infecciosas y Microbiología, 31, 137-151.

[12] Jhon, D., Ruiz, B., Suárez, M.C. and Catalina, U. (2006) Susceptibilidad antimicrobiana in Vitro de cepas de Salmonella spp. en granjas de ponedoras comerciales del departamento de Antioquia. Revista Colombiana de Ciencias Pecuarias, 19, $297-$ 305.

[13] Romero Cabello, R. (2007) Microbiología y parasitología humana/Microbiology and Human Parasitology: Bases etiológicas de las enfermedades infecciosas y parasitarias/Etiological Basis of Infectious and Parasitic Diseases. Tercera edición, Médica Panamericana.

[14] ELIKA (2013) Fundación Vasca para la seguridad agroalimentaria. Salmonella. http://www.elika.eus/datos/pdfs_agrupados/Documento82/1.Salmonella.pdf

[15] Heredia, N., Dávila-Aviña, J.E., Solís Soto, L. and García, S. (2014) Meat Products: Main Pathogens and Non-Thermal Control Strategies. Nacameh, 8, S20-S42.

[16] Issenhuth-Jeanjean, S., Roggentin, P., Mikoleit, M., Guibourdenche, M., de Pinna, E., Nair, S., Fields P.I. and Weill, F.X. (2014) Supplement 2008-2010 (No. 48) to the White-Kauffmann Le Minor Scheme. Research in Microbiology, 165, 526-530. https://doi.org/10.1016/j.resmic.2014.07.004

[17] Méndez, I.A., Badillo, C.A., Parra, G.O. and Faccini, Á.A. (2011) Caracterización microbiológica de Salmonella en alimentos de venta callejera en un sector universitario de Bogotá, Colombia. Revista Médicas UIS, 24, 23-29.

[18] Calderón, L.G.R., Delgado, P.A.M., Urbano, M.F.C. and Coy, F.A.C. (2013) Resistance of Salmonella to Conventional Antimicrobials for Their Treatment. CES Medicina Veterinaria y Zootecnia, 7, 115-127.

[19] Puig Peña, Y., Espino Hernández, M. and Leyva Castillo, V. (2011) Resistencia Anti-Microbiana en Salmonella y E. coli aisladas de alimentos: Revisión de la literatura. Panorama Cuba y Salud, 6, 30-38.

[20] Romero Cabello, R. (1999) Microbiología y parasitología humana. Bases etiológicas de las enfermedades infecciosas. 2da edición, Editorial medica panamericana, 298.

[21] WHO-OMS (2016) World Health Organization-Organización Mundial de la Salud. Temas de salud, Salmonelosis. http://www.who.int/topics/salmonella/es/

[22] Jarvis, N.A., O’Bryan, C.A., Dawoud, T.M., Park, S.H., Kwon, Y.M., Crandall, P.G. and Ricke, S.C. (2016) An Overview of Salmonella Thermal Destruction during Food Processing and Preparation. Food Control, 68, 280-290.

https://doi.org/10.1016/j.foodcont.2016.04.006

[23] Hansen, B.T., Nielsen, L.N., Christensen, B.B. and Aabo, A. (2016) Enterococci as Indicator of Potential Growth of Salmonella in Fresh Minced Meat at Retail. Food Microbiology, 59, 92-96. https://doi.org/10.1016/j.fm.2016.05.010

[24] NORMA Official Mexicana NOM-210-SSA1-2014. Productos y servicios. Métodos de prueba microbiológicos. Determinación de microorganismos indicadores. Determinación de microorganismos patógenos. 
http://www.economia-noms.gob.mx/noms/inicio.do

[25] NORMA Official Mexicana NOM-243-SSA1-2010. Productos y servicios. Leche, fórmula láctea, producto lácteo combinado y derivados lácteos. Disposiciones y especificaciones sanitarias. Métodos de prueba.

http://www.economia-noms.gob.mx/noms/detalleXNormaAction.do

[26] NORMA Official Mexicana NOM-242-SSA1-2009. Productos y servicios. Productos de la pesca frescos, refrigerados, congelados y procesados. Especificaciones sanitarias y métodos de prueba.

http://www.economia-noms.gob.mx/noms/detalleXNormaAction.do

[27] Bou, G., Fernández-Olmos, A., García, C., Sáez-Nieto, J.A. and Valdezate, S. (2011) Bacterial Identification Methods in the Microbiology Laboratory. Enfermedades Infecciosas y Microbiología Clínica, 29, 601-608.

https://doi.org/10.1016/j.eimc.2011.03.012

[28] Olmos Fernández, A., García de la Fuente, C., Sáez Nieto Juan, A. and Valdezate Ramos, S. (2010) Procedimientos en microbiología clínica. Recomendaciones de la sociedad española de enfermedades infecciosas y microbiología clínica. Métodos de identificación bacteriana en el laboratorio de microbiología. SEIMC.

https://www.seimc.org/contenidos/documentoscientificos/procedimientosmicrobiol ogia/seimc-procedimientomicrobiologia37.pdf

[29] Wallace, H.A., Andrew, J. and Thomas, H. (2014) Bacteriological Analytical Manual: Salmonella. Chapter 5.

http://www.fda.gov/Food/FoodScienceResearch/LaboratoryMethods/ucm070149.htm

[30] ISO 6579 (2002) Microbiology of Food and Animal Feeding Stuffs-Horizontal Method for the Detection of Salmonella spp. 4th Edition.

[31] Perilla Mindy, J., Ajello, G., Bopp, C., Elliott, J., Facklam, R., Knapp, J.S., Popovic, T., Wells, J. and Dowell, S.F. (2004) Manual de Laboratorio para la Identificación y Prueba de Susceptibilidad a los Antimicrobianos de Patógenos Bacterianos de Importancia para la Salud Pública en el Mundo en Desarrollo. Haemop-hilus influenzae, Neisseria meningitidis, Streptococcus pneumoniae, Neisseria gono-rrhoeae, Salmonella serotipo Typhi, Shigella y Vibrio cholerae. Centros para el Control y la Prevención de Enfermedades, Atlanta, Georgia, EUA, Organización Mundial de la Salud (CDC-WHO).

http://apps.who.int/medicinedocs/documents/s16330e/s16330e.pdf

[32] Cabrera, C.E., Gómez, R.F. and Zúñiga, A.E. (2007) La resistencia de bacterias a antibióticos, antisépticos y desinfectantes una manifestación de los mecanismos de supervivencia y adaptación. Colombia Médica, 38, 149-158.

[33] Tafur, J.D., Torres, J.A. and Villegas, M.V. (2008) Mechanisms of Antibiotic Resistance in Gram Negative Bacteria. Infect, 12, 227-232.

[34] Becerra, G., Plascencia, A., Luévanos, A., Domínguez, M. and Hernández, I. (2009) Mecanismo de resistencia a antimicrobianos en bacterias. Enfermedades Infecciosas y Microbiología, 29, 70-76.

[35] Gallardo, F., Soto, S.M., Vila, J., de Anta Losada, M.T.J. and Ruiz, J. (2003) Distintos mecanismos de resistencia asociados a integrones en aislamientos clínicos de Salmonella typhimurium. Revista Española de Quimioterapia, 16, 398-402.

[36] Puig Peña, Y., Espino Hernández, M., Leyva Castillo, V., Zagovalov, M., Kely, T., Méndez Morales, D. and Ferrer Márquez, Y. (2007) Susceptibilidad antimicrobiana en cepas de Salmonella spp. de origen clínico y alimentario. Revista Panamericana de Infectología, 9, 12-16.

[37] López Cuevas, O., León Félix, J., Jiménez Edeza, M. and Chaidez Quiroz, C. (2009) Detección y resistencia a antibióticos de Escherichia coli y Salmonella en agua y su- 
elo agrícola. Revista Fitotecnia Mexicana, 32, 119-126.

[38] Bermúdez, P.M., Pulecio, S.L. and Suárez, M.C. (2016) Susceptibilidad anti-microbiana de aislamientos de Salmonella enterica provenientes de pisos, equipos, utensilios y producto terminado en el beneficio porcino en Colombia. Revista de la Facultad de Medicina Veterinaria y de Zootecnia, 63, 39-53. https://doi.org/10.15446/rfmvz.v63n1.56903

[39] Waldner, L.L., Mackenzie, K.D., Koster, W. and White, A.P. (2012) From Exit to Entry: Long-Term Survival and Transmission of Salmonella. Pathogens, 1, 128-155. https://doi.org/10.3390/pathogens1020128

[40] Lee, C.J., Su, L.H., Huang, Y.C. and Chiu C.H. (2015) First Isolation CiprofloxacinResistent Salmonella Enterica Serovar Thypi in Taiwan. Journal of Microbiology, Immulogy and Infection, 46, 469-473. https://doi.org/10.1016/j.jmii.2013.01.002

[41] Hernández, B.B. and Godoy, J.H. (2004) Antibiotic Resistances in Listeria monocytogenes and Salmonella Enterica Isolated from Foods with Animal Origin. Revista Salud Ambienta, 41, 42-46.

[42] Nayarit-Ballesteros, N., Rubio-Lozano, M.S., Delgado-Suárez, E., Méndez-Medina, D., Braña-Varela, D. and Rodas-Suárez, O. (2016) Perfil de resistencia a antibióticos de serotipos de Salmonella spp. aislados de carne de res molida en la Ciudad de México. Salud Pública de México, 58, 371-377. https://doi.org/10.21149/spm.v58i3.7897

[43] Miranda, J.M., Mondragón, A.C., Martínez, B., Guarddon, M. and Rodríguez, J.A. (2009) Prevalence and Antimicrobial Resistance Patterns of Salmonella from Different Raw Foods in Mexico. Journal of Food Protection, 72, 966-971. https://doi.org/10.4315/0362-028X-72.5.966

[44] López, A., Ruiz, A.C., Cabrera, C., León, G. and Tejeda, F. (2014) Prevalencia de cepas multirresistentes de Salmonella spp y Escherichia coli 0157:H7 en alimentos crudos en la Ciudad de Puebla. Ciencias Naturales y Exactas, Guanajuato.

\section{Submit or recommend next manuscript to SCIRP and we will provide best service for you:}

Accepting pre-submission inquiries through Email, Facebook, LinkedIn, Twitter, etc. A wide selection of journals (inclusive of 9 subjects, more than 200 journals)

Providing 24-hour high-quality service

User-friendly online submission system

Fair and swift peer-review system

Efficient typesetting and proofreading procedure

Display of the result of downloads and visits, as well as the number of cited articles

Maximum dissemination of your research work

Submit your manuscript at: http://papersubmission.scirp.org/

Or contact jbm@scirp.org 